\title{
GARIS DI LAPANGAN HIMPUNAN BILANGAN BULAT MODULO 17
}

\author{
Denni Hariati Sinaga, Idha Sihwaningrum, dan Ari Wardayani \\ Program Studi Matematika, Fakultas Sains dan Teknik \\ Universitas Jenderal Soedirman \\ Email : denni_hs@yahoo.com, idhasihwaningrum@yahoo.com, \\ ariwardayani@yahoo.co.id
}

\begin{abstract}
In this paper we discuss rational trigonometry in the field $\mathrm{F}_{17}$, in particular point, lines and their properties. A unique property in this field is given by the null lines.
\end{abstract}

Key words: rational trigonometry, the field $\mathrm{F}_{17}$, line, null line

ABSTRAK. Pada artikel ini dikaji trigonometri rasional di lapangan $\mathrm{F}_{17}$, khususnya mengenai pengertian titik dan garis beserta sifat-sifatnya. Salah satu sifat unik garis di lapangan ini diberikan oleh garis nol.

Kata kunci: Trigonometri rasional, lapangan $\mathrm{F}_{17}$, garis, garis nol.

\section{PENDAHULUAN}

Trigonometri berasal dari bahasa Yunani yaitu trigonon dan metron. Trigonon berarti segitiga dan metron berarti mengukur. Dengan demikian, trigonometri berarti pengukuran segitiga (Rich dan Schmidt, 2003). Trigonometri dibagi menjadi 2 jenis yaitu trigonometri klasik dan rasional. Trigonometri klasik membahas tentang garis dan segitiga pada lapangan himpunan bilangan riil. Sementara itu, trigonometri rasional membahas tentang garis dan segitiga pada berbagai lapangan, misalnya lapangan himpunan bilangan riil, lapangan himpunan bilangan kompleks, lapangan himpunan bilangan rasional, dan lapangan himpunan bilangan bulat modulo $p$ (dengan $p$ bilangan prima). Jadi, trigonometri rasional mempunyai cakupan lebih luas dibandingkan trigonometri klasik, maka penulis tertarik mengkaji trigonometri rasional, khususnya mengenai garis pada $\mathrm{F}_{p}$, yaitu lapangan himpunan bilangan bulat modulo $p$ (dengan $p$ bilangan prima). Pada Wildberger (2005) hanya diberikan contoh titik dan garis di lapangan $F_{11}$ dan $F_{13}$ sehingga pada makalah ini akan dibahas secara lengkap mengenai garis di lapangan $\mathrm{F}_{17}$ beserta sifat-sifatnya. 


\section{HASIL DAN PEMBAHASAN}

Garis di lapangan $F_{17}$ berbeda dengan garis di lapangan himpunan bilangan riil. Pada lapangan $\mathrm{F}_{17}$, garis direpresentasikan dengan cara menggambar semua titik yang memenuhi persamaan garis tersebut. Oleh sebab itu, subbab ini diawali dengan bahasan mengenai titik di lapangan $F_{17}$. Pengertian, definisi, dan teorema diambil dari Wildberger (2005), tetapi contoh-contoh dan pembuktian teorema diberikan oleh penulis.

\subsection{Titik di Lapangan $F_{17}$}

Koordinat Kartesius pada lapangan $\mathrm{F}_{17}$ direpresentasikan oleh persegi besar yang dibagi menjadi $17 \times 17$ persegi kecil yang sama besar. Sumbu horizontal $\mathrm{X}$ dan sumbu vertikal $\mathrm{Y}$ diberi nomor dari 0 sampai 16. Kemudian, titik $[x, y]$ pada koordinat Kartesius di lapangan $\mathrm{F}_{17}$ direpresentasikan dengan kotak hitam, lingkaran kecil, segitiga atau simbol lain. Contoh titik pada koordinat Kartesius di lapangan $\mathrm{F}_{17}$ diberikan pada gambar berikut.

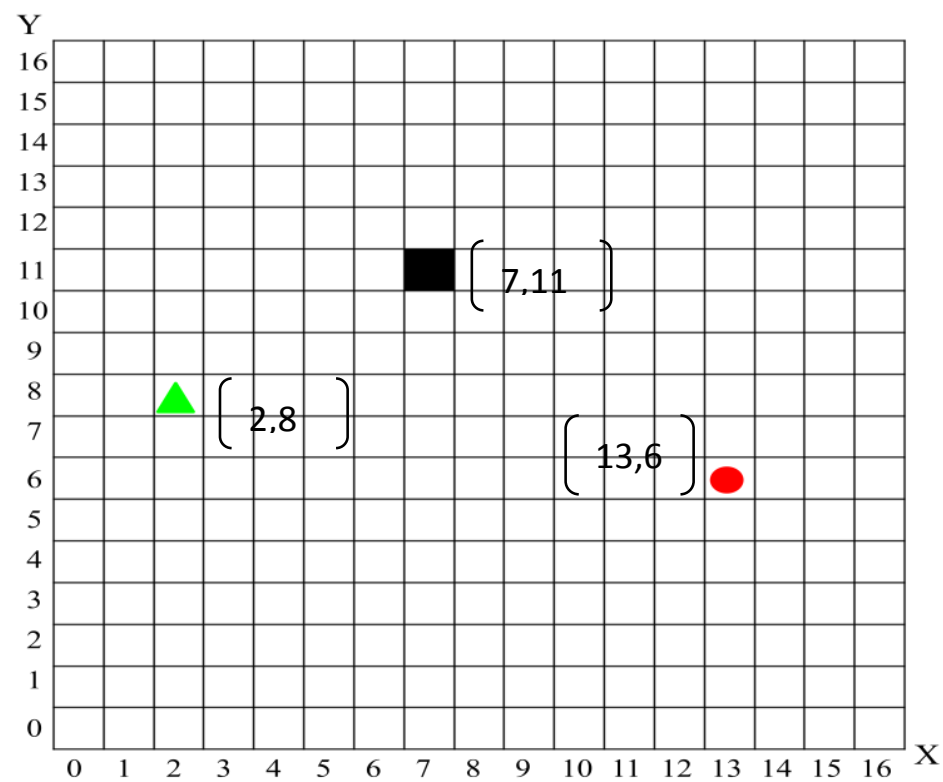

Gambar 1. Titik [2, 8], [7, 11] dan [13,6] di lapangan $F_{17}$ 
Pada Gambar 1, titik [2, 8] direpresentasikan dengan segitiga hijau, titik [7, 11] direpresentasikan dengan kotak hitam, dan titik [13,6] direpresentasikan dengan lingkaran merah.

\subsection{Garis di Lapangan $F_{17}$}

Lapangan $F_{17}$ dilengkapi dengan operasi penjumlahan yang dilambangkan dengan $\oplus_{17}$ dan operasi perkalian yang dilambangkan dengan $\otimes_{17}$. Misal diberikan garis $\ell:=\langle 3: 7: 4\rangle$ di lapangan $\mathrm{F}_{17}$, maka semua titik $[x, y]$ yang memenuhi persamaan $\left(3 \otimes_{17} x\right) \oplus_{17}\left(7 \otimes_{17} y\right) \oplus_{17} 4=0$ membentuk garis $\ell$ di lapangan $F_{17}$.

Titik-titik yang memenuhi persamaan tersebut adalah titik [0, 14], [1, 16], [2, 1], $[3,3],[4,5],[5,7],[6,9],[7,11],[8,13],[9,15],[10,0],[11,2],[12,4],[13,6]$, $[14,8]$, [15, 10], dan [16, 12]. Jadi, garis $\ell$ dapat digambarkan seperti pada Gambar 2 berikut.

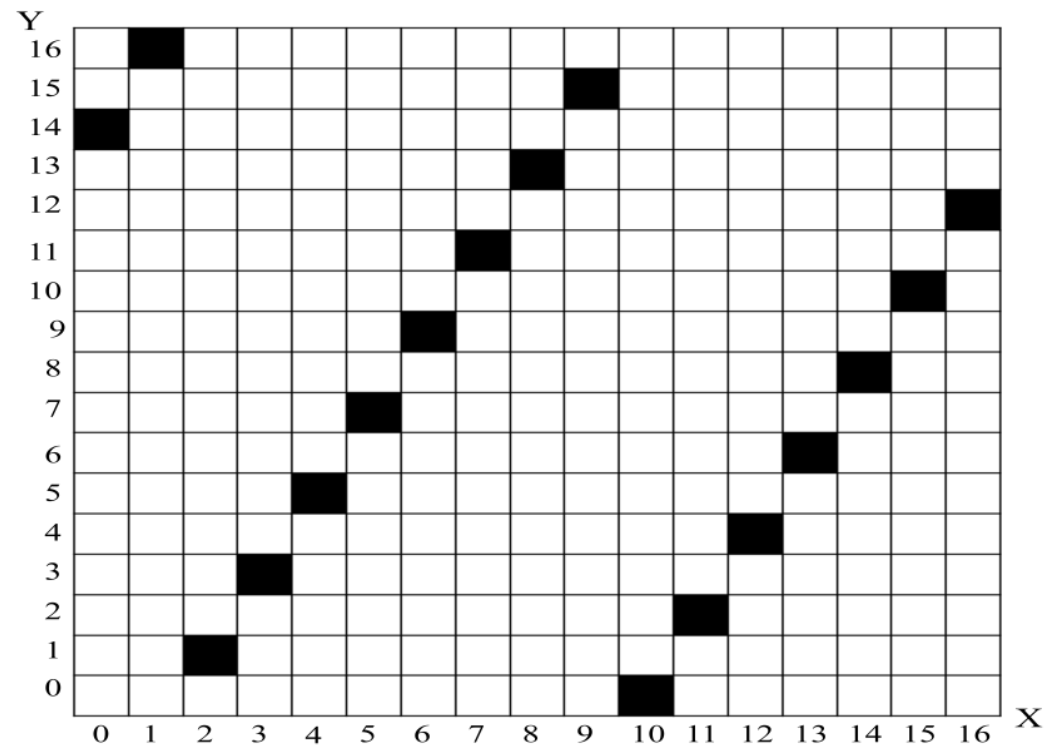

Gambar 2. Garis $\ell:=\langle 3: 7: 4\rangle$ di lapangan $\mathrm{F}_{17}$

Kemudian, sembarang dua titik yang berbeda selalu mempunyai jarak. Misalkan titik $A_{1}:=\left[x_{1}, y_{1}\right]$ dan $A_{2}:=\left[x_{2}, y_{2}\right]$, maka jarak antara titik $A_{1}$ dengan $A_{2}$ adalah $\sqrt{\left(x_{2}-x_{1}\right)^{2}+\left(y_{2}-y_{1}\right)^{2}}$ dan garis yang melalui kedua titik tersebut adalah 
$\left\langle y_{1}-y_{2}: x_{2}-x_{1}: x_{1} y_{2}-x_{2} y_{1}\right\rangle$. Pada trigonometri rasional, kuadrat dari jarak disebut dengan quadrance. Jadi, quadrance dari titik $A_{1}$ ke titik $A_{2}$ adalah $\left(x_{2}-x_{1}\right)^{2}+\left(y_{2}-y_{1}\right)^{2}$. Akibatnya, titik-titik yang berjarak nol mempunyai quadrance nol. Sebagai contoh, di lapangan $\mathrm{F}_{17}$ quadrance dari titik $[1,0]$ ke titik $[0,4]$ adalah nol, sedangkan quadrance dari titik [2, 3] ke titik [5, 7] adalah 8. Selanjutnya, titik-titik yang mempunyai quadrance nol membentuk garis yang disebut garis nol.

Garis yang melalui titik $\left[x_{1}, y_{1}\right]$ dan $\left[x_{2}, y_{2}\right]$ diberikan oleh $\left\langle y_{1}-y_{2}: x_{2}-x_{1}\right.$ $\left.: x_{1} y_{2}-x_{2} y_{1}\right\rangle$. Garis tersebut dapat ditulis kembali sebagai $\langle a: b: c\rangle$ dengan $a=y_{1}-y_{2}, \quad b=x_{2}-x_{1}$, dan $c=x_{1} y_{2}-x_{2} y_{1}$. Dengan demikian, garis nol dapat didefinisikan sebagai berikut.

Definisi 2.1 (Garis Nol). Garis $\ell:=\langle a: b: c\rangle$ adalah garis nol apabila $a^{2}+b^{2}=0$. Selain itu, garis $\ell$ disebut garis tak nol.

Pada lapangan himpunan bilangan riil tidak terdapat garis nol karena quadrance antara dua titik yang bernilai nol hanya dipenuhi oleh quadrance dari titik ke dirinya sendiri.

\section{Contoh 1}

Diberikan garis $\ell:=\langle 1: 4: 3\rangle$ di lapangan $F_{17}$. Menurut Definisi 3.1, garis $\ell$ merupakan garis nol karena $1^{2} \oplus_{17} 4^{2}=1 \oplus_{17} 16=0$. Gambar 3 berikut adalah gambar garis $\ell:=\langle 1: 4: 3\rangle$ di lapangan $\mathrm{F}_{17}$. 


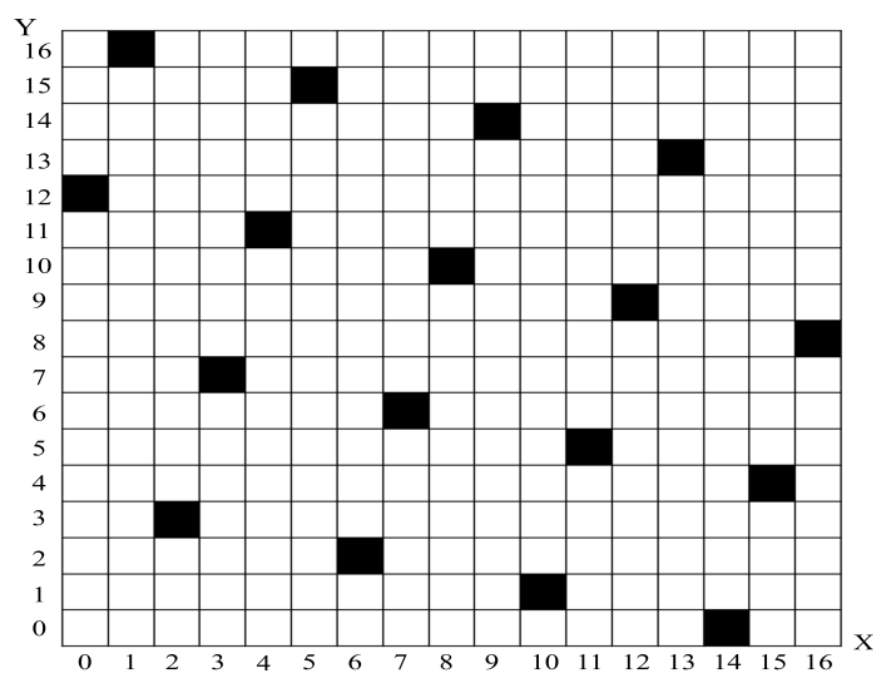

Gambar 3. Garis nol $\ell:=\langle 1: 4: 3\rangle$ di lapangan $F_{17}$

Teorema 2.1. Untuk setiap titik di lapangan $\mathrm{F}_{17}$, terdapat tepat dua garis nol yang melalui titik tersebut.

Bukti. Ambil sembarang titik $[x, y]$ di lapangan $\mathrm{F}_{17}$. Titik tersebut dilalui oleh garis nol atau garis tak nol. Andaikan titik $[x, y]$ dilalui oleh garis nol $\ell:=\left\langle a: b: c_{1}\right\rangle$, maka $\left(a \otimes_{17} x\right) \oplus_{17}\left(b \otimes_{17} y\right) \oplus_{17} c_{1}=0$ sehingga diperoleh $c_{1}=-\left(a \otimes_{17} x\right) \oplus_{17}-\left(b \otimes_{17} y\right)$. Karena garis $\ell$ merupakan garis nol, maka

$$
a^{2} \oplus_{17} b^{2}=0 \text {. }
$$

Padahal, $a^{2}=(-a)^{2}$ dan $b^{2}=(-b)^{2}$ dengan $-a,-b$ masing-masing adalah invers dari $a$ dan $b$ terhadap operasi $\oplus_{17}$. Akibatnya,

$$
a^{2} \oplus_{17}(-b)^{2}=0 \text { atau }(-a)^{2} \oplus_{17} b^{2}=0 .
$$

Dengan mensubstitusikan $c_{1}=-\left(a \otimes_{17} x\right) \oplus_{17}-\left(b \otimes_{17} y\right)$ ke persamaaan

$$
\left(a \otimes_{17} x\right) \oplus_{17}\left(b \otimes_{17} y\right) \oplus_{17} c_{1}=0,
$$

diperoleh persamaan

$$
\left(a \otimes_{17} x\right) \oplus_{17}\left(b \otimes_{17} y\right) \oplus_{17}-\left(a \otimes_{17} x\right) \oplus_{17}-\left(b \otimes_{17} y\right)=0 .
$$

Perhatikan bahwa dengan mengganti nilai $b$ dengan $-b$ pada persamaan

$$
\left(a \otimes_{17} x\right) \oplus_{17}\left(b \otimes_{17} y\right) \oplus_{17}-\left(a \otimes_{17} x\right) \oplus_{17}-\left(b \otimes_{17} y\right)=0,
$$


diperoleh persamaan

$$
\left(a \otimes_{17} x\right) \oplus_{17}\left(-b \otimes_{17} y\right) \oplus_{17}-\left(a \otimes_{17} x\right) \oplus_{17}\left(b \otimes_{17} y\right)=0 .
$$

Dengan mengambil $c_{2}=-\left(a \otimes_{17} x\right) \oplus_{17}\left(b \otimes_{17} y\right)$, maka terdapat garis nol lainnya yang melewati titik $[x, y]$ yaitu $\ell_{1}:=\left\langle a:-b: c_{2}\right\rangle:=\left\langle a:-b:-\left(a \otimes_{17} x\right) \oplus_{17}\left(b \otimes_{17} y\right)\right\rangle$. Selanjutnya, persamaan $\left(a \otimes_{17} x\right) \oplus_{17}\left(-b \otimes_{17} y\right) \oplus_{17}-\left(a \otimes_{17} x\right) \oplus_{17}\left(b \otimes_{17} y\right)=0$ sama dengan persamaan $\left(-a \otimes_{17} x\right) \oplus_{17}\left(b \otimes_{17} y\right) \oplus_{17}\left(a \otimes_{17} x\right) \oplus_{17}-\left(b \otimes_{17} y\right)=0$. Hal tersebut mengakibatkan, garis $\ell_{1}:=\left\langle a:-b:-\left(a \otimes_{17} x\right) \oplus_{17}\left(b \otimes_{17} y\right)\right\rangle:=$ $\left\langle-a: b:\left(a \otimes_{17} x\right) \oplus_{17}-\left(b \otimes_{17} y\right)\right\rangle$. Dengan demikian, terbukti bahwa untuk sembarang titik $[x, y]$ dilalui tepat dua garis nol yaitu garis $\ell:=\left\langle a: b: c_{1}\right\rangle$ dan $\ell_{1}:=\left\langle a:-b:-\left(a \otimes_{17} x\right) \oplus_{17}\left(b \otimes_{17} y\right)\right\rangle$

\section{Contoh 2}

Jika diberikan titik $[4,2]$ yang dilalui oleh garis nol $\ell_{1}:=\langle 5: 14: 3\rangle$, maka menurut Teorema 3.2, terdapat garis nol lainnya yang melalui titik $[4,2]$, yaitu garis $\ell_{2}:=\left\langle a:-b:-\left(a \otimes_{17} x\right) \oplus_{17}\left(b \otimes_{17} y\right)\right\rangle:=\left\langle 5:-14:-\left(5 \otimes_{17} 4\right) \oplus_{17}\left(14 \otimes_{17} 2\right)\right\rangle$ $:=\langle 5: 3: 8\rangle$. Gambar kedua garis nol tersebut diberikan pada Gambar 4. Pada gambar tersebut, garis nol $\ell_{1}:=\langle 5: 14: 3\rangle$ direpresentasikan dengan kotak-kotak biru, sedangkan garis nol $\ell_{2}:=\langle 5: 3: 8\rangle$ direpresentasikan dengan lingkaran-lingkaran merah dan titik $[4,2]$ direpresentasikan dengan kotak yang terdiri dari kotak biru dan lingkaran merah. 


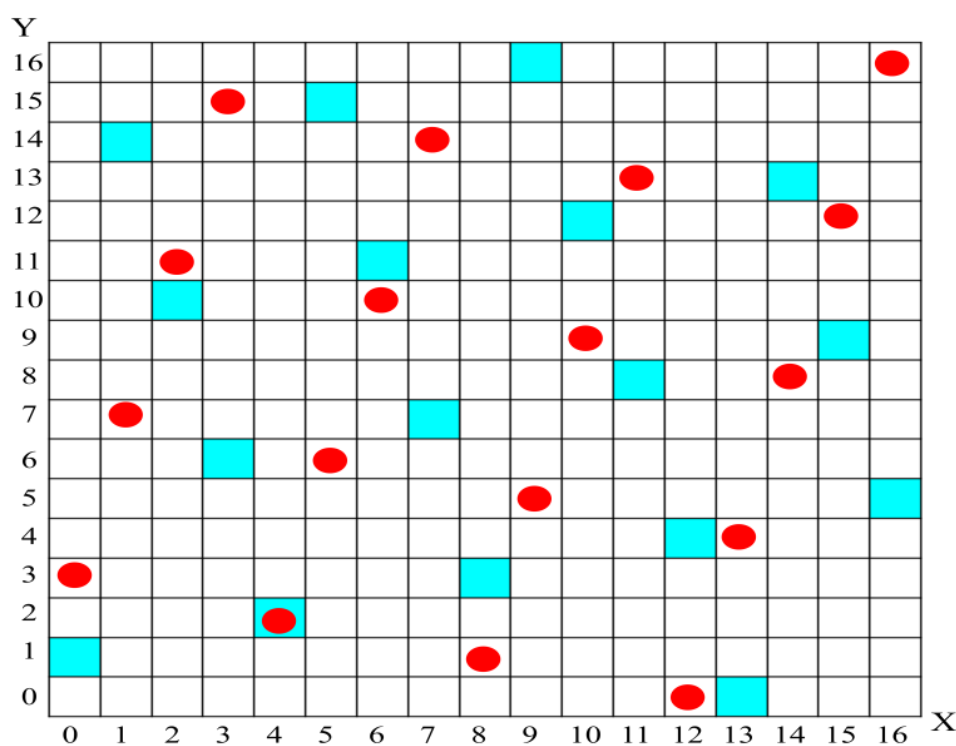

Gambar 4. Titik $[4,2]$ yang dilalui dua garis nol $\ell_{1}:=\langle 5: 14: 3\rangle$ dan $\ell_{2}:=\langle 5: 3: 8\rangle$

Teorema 2.2. Setiap garis di lapangan $\mathrm{F}_{17}$ melalui tepat 17 titik.

\section{Contoh 3}

Misal diberikan garis $\ell:=\langle 4: 7: 0\rangle$ di lapangan $F_{17}$. Menurut Teorema 3.3, garis $\ell$ melalui tepat 17 titik. Titik yang dilalui oleh garis $\ell$ adalah [0, 0], [1, 14], [2, 11], $[3,8],[4,5],[5,2],[6,16],[7,13],[8,10],[9,7],[10,4],[11,1],[12,15]$, $[13,12],[14,9],[15,6],[16,3]$. Garis $\ell:=\langle 4: 7: 0\rangle$ digambarkan pada Gambar 5 berikut. 


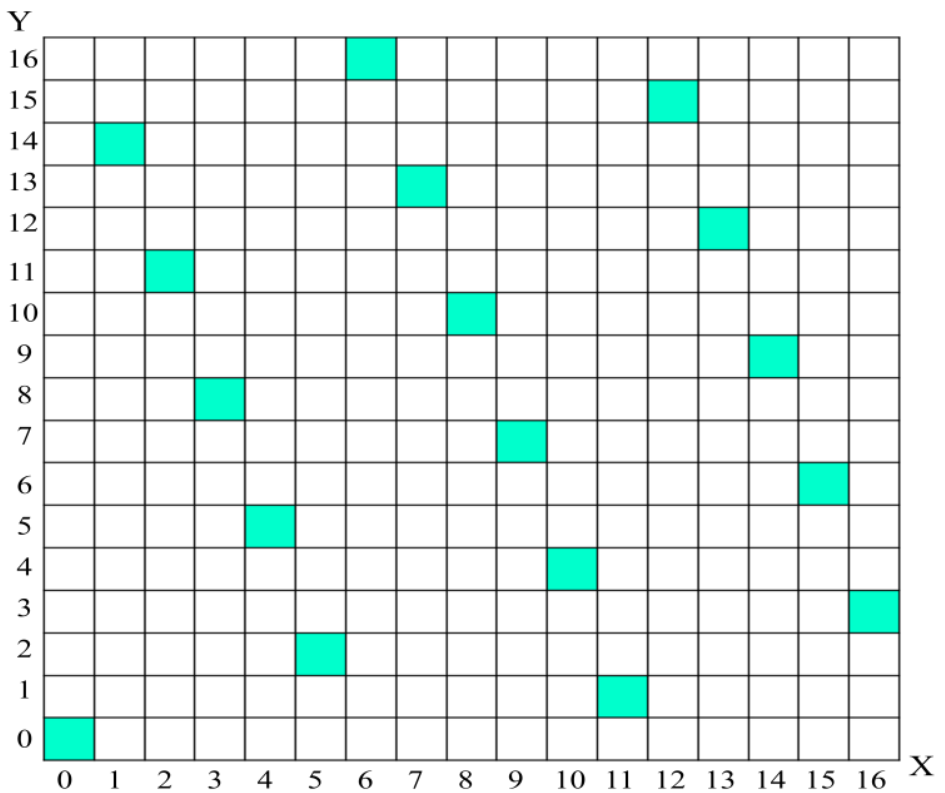

Gambar 5. Garis $\ell:=\langle 4: 7: 0\rangle$ melalui tepat 17 titik

Teorema 2.3. Untuk setiap titik di lapangan $\mathrm{F}_{17}$, terdapat tepat 18 garis yang melalui titik tersebut.

\section{Contoh 4}

Diberikan titik [3, 5] di lapangan $\mathrm{F}_{17}$. Menurut Teorema 3.4, titik [3, 5] dilalui tepat 18 garis yaitu $\langle 16: 1: 15\rangle,\langle 15: 1: 1\rangle,\langle 14: 1: 4\rangle,\langle 13: 1: 7\rangle,\langle 12: 1: 10\rangle$, $\langle 11: 1: 13\rangle,\langle 10: 1: 16\rangle,\langle 9: 1: 2\rangle,\langle 8: 1: 5\rangle,\langle 7: 1: 8\rangle,\langle 6: 1: 11\rangle,\langle 5: 1: 14\rangle$, $\langle 4: 1: 0\rangle,\langle 3: 1: 3\rangle,\langle 2: 1: 6\rangle,\langle 1: 1: 9\rangle,\langle 0: 1: 12\rangle$ dan $\langle 16: 0: 3\rangle$. Kedelapan belas garis yang melalui titik [3,5] diberikan pada Gambar 6. Pada gambar tersebut, titik $[3,5]$ direpresentasikan dengan bintang biru, sedangkan garis $\langle 16: 1$ : 15 direpresentasikan dengan kotak-kotak hijau, $\langle 15: 1: 1\rangle$ direpresentasikan dengan kotak-kotak merah muda, $\langle 14: 1: 4\rangle$ direpresentasikan dengan lingkaranlingkaran biru muda, $\langle 13: 1: 7\rangle$ direpresentasikan dengan lingkaran-lingkaran hijau, $\langle 12: 1: 10\rangle$ direpresentasikan dengan lingkaran-lingkaran merah muda, $\langle 11: 1: 13\rangle$ direpresentasikan dengan segitiga-segitiga merah muda, $\langle 10: 1: 16\rangle$ direpresentasikan dengan lingkaran-lingkaran kuning, $\langle 9: 1: 2\rangle$ direpresentasikan dengan lingkaran-lingkaran biru tua, $\langle 8: 1: 5\rangle$ direpresentasikan dengan 
lingkaran-lingkaran hitam, $\langle 7: 1: 8\rangle$ direpresentasikan dengan lingkaranlingkaran cokelat, $\langle 6: 1: 11\rangle$ direpresentasikan dengan segitiga-segitiga hijau, $\langle 5: 1: 14\rangle$ direpresentasikan dengan segitiga-segitiga hitam, $\langle 4: 1: 0\rangle$ direpresentasikan dengan kotak-kotak cokelat, $\langle 3: 1: 3\rangle$ direpresentasikan dengan kotak-kotak hitam, $\langle 2: 1: 6\rangle$ direpresentasikan dengan kotak-kotak biru tua, $\langle 1: 1: 9\rangle$ direpresentasikan dengan kotak-kotak kuning, $\langle 0: 1: 12\rangle$ direpresentasikan dengan kotak-kotak biru muda, dan garis $\langle 16: 0: 3\rangle$ direpresentasikan dengan kotak-kotak merah tua. Garis $\langle 13: 1: 7\rangle$ dan $\langle 4: 1: 0\rangle$ merupakan garis nol karena $13^{2} \oplus_{17} 1^{2}=0$ dan $4^{2} \oplus_{17} 1^{2}=0$.

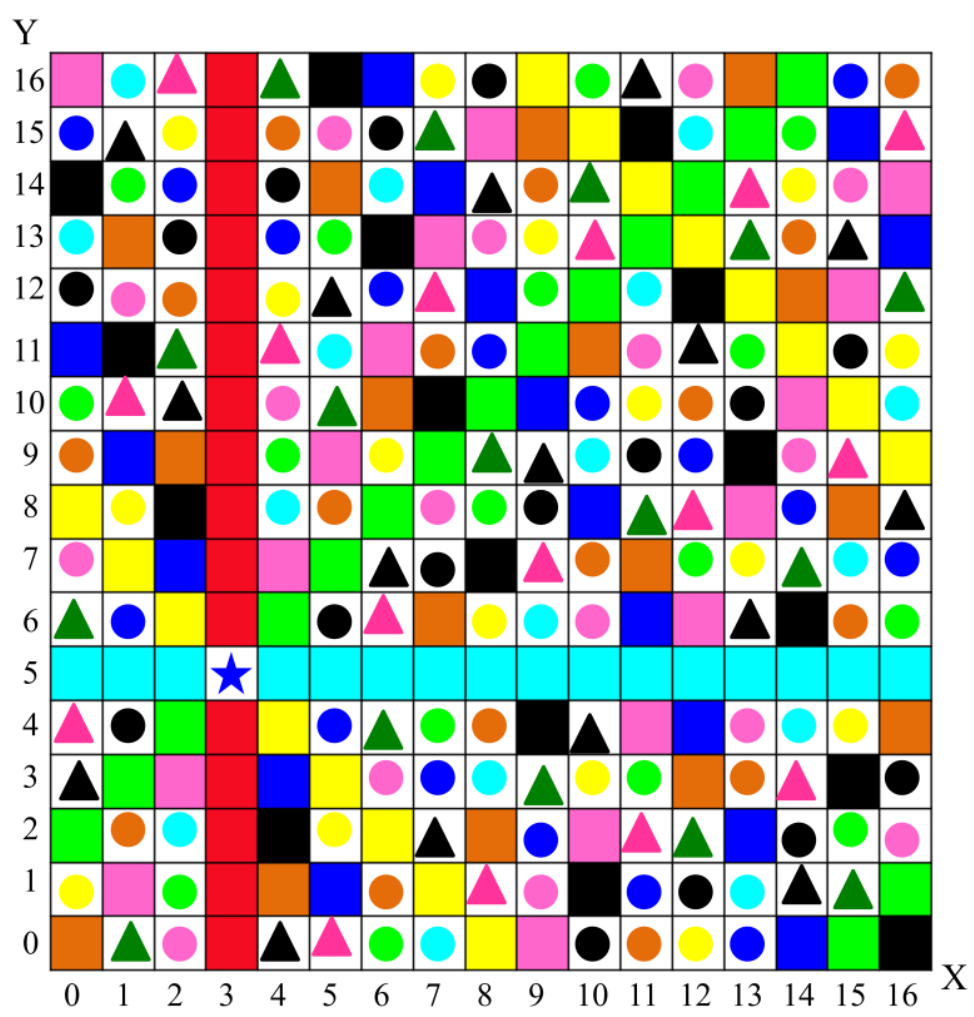

Gambar 6. Garis-garis yang melalui titik $[3,5]$ 


\subsection{Garis Sejajar dan Tegak Lurus}

Pada sub bab ini, dibahas mengenai garis sejajar dan tegak lurus di lapangan $\mathrm{F}_{17}$. Garis $\ell_{1}:=\left\langle a_{1}: b_{1}: c_{1}\right\rangle$ dan $\ell_{2}:=\left\langle a_{2}: b_{2}: c_{2}\right\rangle$ sejajar apabila $a_{1} b_{2}-$ $a_{2} b_{1}=0$. Kedua garis tersebut tegak lurus apabila $a_{1} a_{2}+b_{1} b_{2}=0$.

Teorema 3.4. Jika garis $\ell_{1}$ dan $\ell_{2}$ sejajar dan sekaligus tegak lurus, maka kedua garis tersebut adalah garis nol.

Bukti. Misalkan garis $\ell_{1}:=\left\langle a_{1}: b_{1}: c_{1}\right\rangle$ dan $\ell_{2}:=\left\langle a_{2}: b_{2}: c_{2}\right\rangle$ di lapangan $\mathrm{F}_{17}$. Karena garis $\ell_{1}, \ell_{2}$ sejajar dan tegak lurus, maka $\frac{a_{1}}{b_{1}}=\frac{a_{2}}{b_{2}}$ dan $\frac{a_{1}}{b_{1}}=\frac{-b_{2}}{a_{2}}$. Ini memberikan $\frac{a_{2}}{b_{2}}=\frac{-b_{2}}{a_{2}}$ sehingga diperoleh $a_{2}^{2} \oplus_{17} b_{2}^{2}=0$. Jadi, $\ell_{2}$ merupakan garis nol. Kemudian, karena $\frac{a_{1}}{b_{1}}=\frac{-b_{2}}{a_{2}}$ maka $\frac{a_{2}}{b_{2}}=-\frac{-b_{1}}{a_{1}}$. Akibatnya, $\frac{a_{1}}{b_{1}}=\frac{a_{2}}{b_{2}}=\frac{-b_{1}}{a_{1}}$. Dengan kata lain, $\frac{a_{1}}{b_{1}}=\frac{-b_{1}}{a_{1}}$ sehingga $a_{1}^{2} \oplus_{17} b_{1}^{2}=0$. Jadi, $\ell_{1}$ merupakan garis nol.

\section{Contoh 5}

Diberikan garis $\ell_{1}:=\langle 2: 9: 4\rangle$ dan $\ell_{2}:=\langle 15: 8: 9\rangle$. Garis $\ell_{1}$ dan $\ell_{2}$ sejajar karena $\left(2 \otimes_{17} 8\right) \Theta_{17}\left(9 \otimes_{17} 15\right)=16 \Theta_{17} 16=0$. Garis $\ell_{1}$ dan $\ell_{2}$ juga tegak lurus karena $\left(2 \otimes_{17} 15\right) \oplus_{17}\left(9 \otimes_{17} 8\right)=13 \oplus_{17} 4=0$. Karena garis $\ell_{1}$ dan $\ell_{2}$ sejajar dan sekaligus tegak lurus, maka menurut Teorema 3.5 kedua garis tersebut merupakan garis nol. Gambar kedua garis tersebut diberikan pada Gambar 7. Pada gambar tersebut, garis $\ell_{1}:=\langle 2: 9: 4\rangle$ direpresentasikan dengan kotak-kotak hitam, sedangkan garis $\ell_{2}:=\langle 15: 8: 9\rangle$ direpresentasikan dengan kotak-kotak merah. 


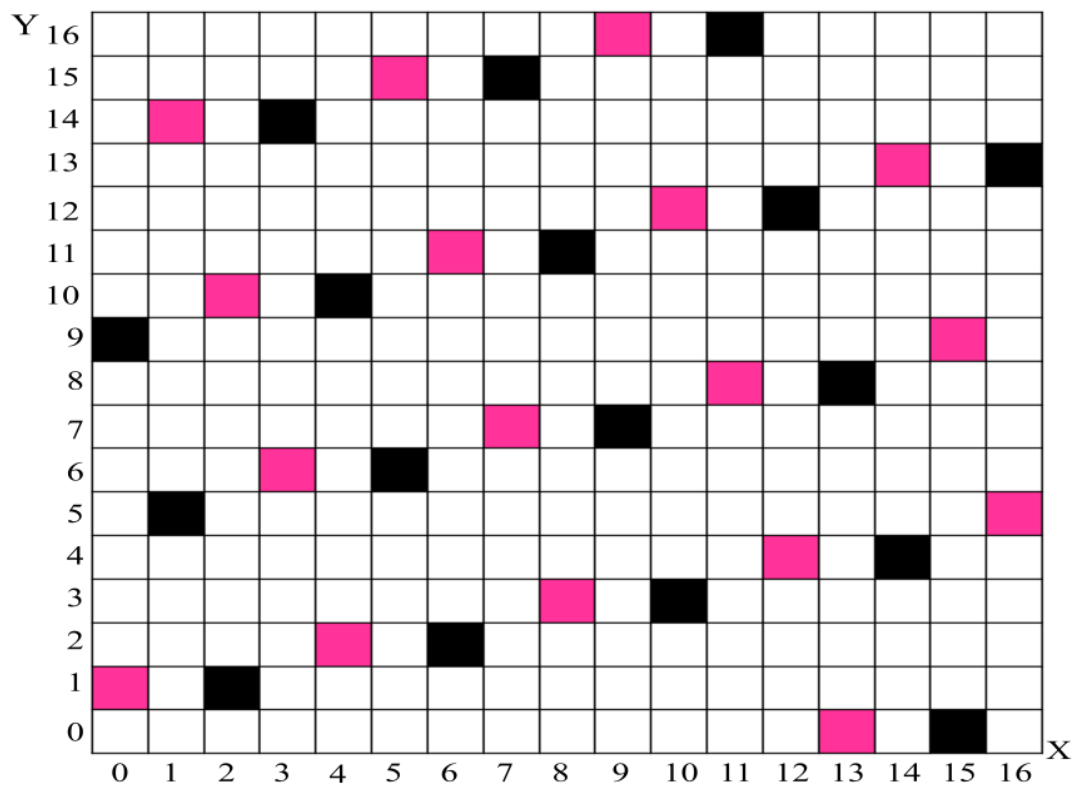

Gambar 7. Garis $\ell_{1}:=\langle 2: 9: 4\rangle$ dan $\ell_{2}:=\langle 15: 8: 9\rangle$ sejajar dan sekaligus tegak lurus

\section{KESIMPULAN DAN SARAN}

\subsection{Kesimpulan}

Pada lapangan $F_{17}$, garis direpresentasikan dengan cara menggambar semua titik yang dilalui garis tersebut. Pada lapangan ini, terdapat garis nol yaitu garis yang titik-titiknya mempunyai quadrance (kuadrat dari jarak) bernilai nol. Garis nol mempunyai sifat bahwa untuk setiap titik di lapangan $F_{17}$, terdapat tepat dua garis nol yang melalui titik tersebut. Kemudian, secara umum sifat-sifat garis di lapangan $F_{17}$ adalah setiap garis di lapangan $F_{17}$ melalui tepat 17 titik dan untuk setiap titik di lapangan $F_{17}$ terdapat tepat 18 garis yang melalui titik tersebut. Selain itu, jika dua garis yang berbeda di lapangan $F_{17}$ sejajar dan sekaligus tegak lurus, maka kedua garis tersebut merupakan garis nol. 


\subsection{Saran}

Dalam makalah ilmiah ini dibahas mengenai garis di lapangan $\mathrm{F}_{17}$. Hasil yang diperoleh dapat digunakan untuk penelitian lanjut mengenai segitiga di lapangan $\mathrm{F}_{17}$.

\section{DAFTAR PUSTAKA}

Rich, B. dan Philip, A. S.(2003), Schaum's Outlines of Elementary Algebra, $3^{\text {rd }}$ Edition, New York: McGraw-Hill.

Wildberger, N.J.( 2005), Divine Proportions: Rational Trigonometry to Universal Geometry, Australia: Wild Egg Pty Ltd. 